\title{
MATHEMATICAL MODELING OF AN ELECTROHYDRAULIC DRIVE FOR A HYDRAULIC TURBINE
}

\author{
A.В. Матросов, Ю.М. Исаев, Р.А. Сунарчин

\begin{abstract}
МАТЕМАТИЧЕСКОЕ МОДЕЛИРОВАНИЕ МНОГОМАШИННОГО СЛЕДЯЩЕГО ЭЛЕКТРОГИДРОПРИВОДА КОЛЬЦЕВОГО ЗАТВОРА гИДРОТУРБИНЫ
\end{abstract}

\begin{abstract}
The results of a systematic study of two mathematical models of a multi-actuator electro-hydraulic drive designed for a ring gate of hydraulic turbine movement are presented in the work. We have investigated the main factors which have a negative impact on the synchronization of the servo cylinder movement, such as the load capacity, the external forces - additionally applied to the servo cylinders, and the manufacturing error of hydraulic cylinder pistons. Functional dependences of the synchronization error from these factors have been obtained. These dependences allow to develop reasonable recommendations for selecting the main parameters of the hydraulic drive and determine the operation regularities of this drive.
\end{abstract}

RING GATE OF HYDRAULIC TURBINE; MULTIACTUATOR HYDRAULIC DRIVE; SYNCRONIZATION OF HYDRAULIC CYLINDER; MATHEMATICAL MODELING; MATLAB.

\begin{abstract}
В статье приводятся результаты систематического исследования двух математических моделей многомашинных следящих гидроприводов, предназначенных для маневрирования кольцевым затвором гидротурбины. Исследованы основные факторы, оказывающие негативное влияние на синхронность работы исполнительных гидродвигателей, такие, как: масса перемещаемой нагрузки; внешние силы, дополнительно прикладываемые к сервоцилиндрам; разница эффективных площадей поршней гидродвигателей, вызванная технологической погрешностью изготовления. Исследование проведено на основе математического моделирования гидропривода в программном пакете MatLab. Получены зависимости относительной ошибки синхронизации перемещения поршней сервоцилиндров от указанных факторов, позволяющие выработать обоснованные рекомендации для выбора основных параметров гидропривода и определить закономерности работы данного привода, которые могут быть использованы в качестве основы для построения методики моделирования многомашинных гидроприводов кольцевых затворов.
\end{abstract}

КОЛЬЦЕВОЙ ЗАТВОР ГИДРОТУРБИНЫ; МНОГОМАШИННЫЙ СЛЕДЯЩИЙ ГИДРОПРИВОД; СИНХРОНИЗАЦИЯ ГИДРОЦИЛИНДРОВ; МАТЕМАТИЧЕСКОЕ МОДЕЛИРОВАНИЕ, МАТLАВ.

To shut-down the supply of water flow to hydraulic turbine in the case of an accident or if need for repair or maintenance work and to reduce leakages through closed guide vanes and prevent the development of a gap cavitation on blades of the guide vanes, pre-turbine gate valve are often set in the penstock. Their alternative are the ring gates, which have the form of annular shield is located between guide vanes and stay vanes. A characteristic feature the gate of this design is use of multi-actuator hydraulic drive for maneuvering of such shield. One of the main requirements for ring gate hydraulic drives is to pro- vide in-phase synchronous motion of all servo motors (usually - cylinders) included in their structure.

The research results of ring gate multi-actuator hydraulic drive, consisting of 6 cylinders and electrohydraulic servo control system are outlined below.

The main purpose of this study was to evaluate the influence of external forces acting on the ring gate and technological errors of pistons manufacturing on synchronicity and in-phase operation of electrohydraulic drive. This evaluate could be the basis for the calculation methodology of ring gates multi-actuator hydraulic drive. 
The primary goals of the study were: obtaining dependencies of displacement pistons synchronization error on external factors: the mass of the movable load, external forces, additionally applied to the hydraulic cylinders, as well as the difference of effective area of the pistons, caused by technological errors of manufacturing; evaluation of influence the ring gate weight on synchronicity of servo actuators rods movement.

Two mathematical models were considered. In the first model, all rods of hydraulic cylinders connected with a common ring by spring linkage and the ring itself was considered absolutely rigid (fig. 1).

Hydraulic system for the first model consisted of six blocks of the same type, with a common control signal. Schematic diagram of such block is shown in fig.2.

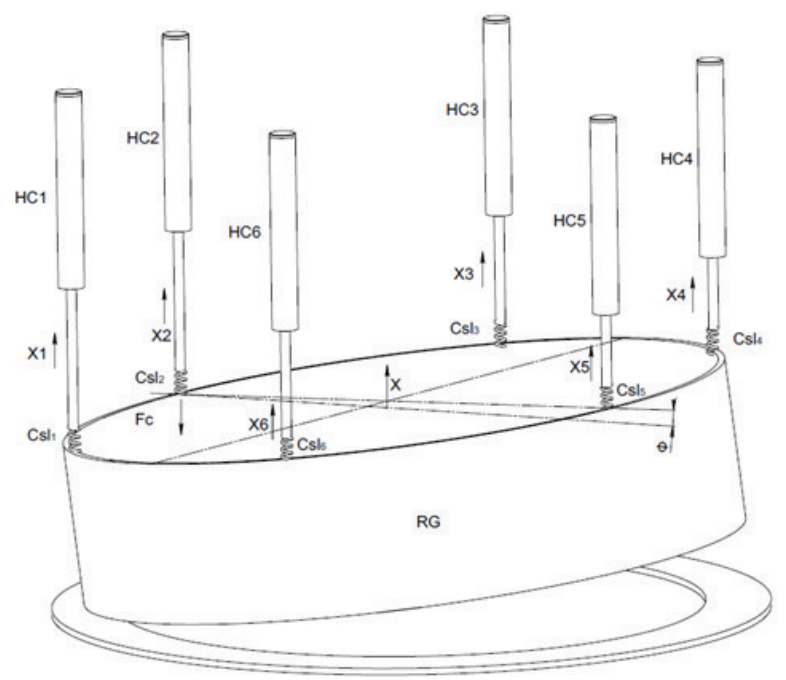

Fig. 1. Kinematic scheme of servodrive: $\mathrm{RG}$ - ring gate; $\mathrm{HC} 1, \ldots \mathrm{HC} 6$ - hydraulic cylinder; X1,..X6 - instantaneous displacement of corresponding hydraulic cylinder;

Csl1,...Csl6 - stiffness of corresponding spring linkage; $\mathrm{X}$ - instantaneous displacement of common ring; $\mathrm{F}_{\mathrm{c}}$ - external forces

In describing mathematical drive model following assumptions were made: parameters are lumped; continuity condition of the working fluid is performed; elasticity modulus of working fluid is constant; throttling gaps flow coefficient of electrohydraulic amplifiers are constant; electrohydraulic amplifiers design is ideal; in mathematical model do not take into account the action of guide supports, on which movement of the gate is performed. Displacements and velocities of hydraulic cylinders and pistons at the initial time were assumed equal to zero.

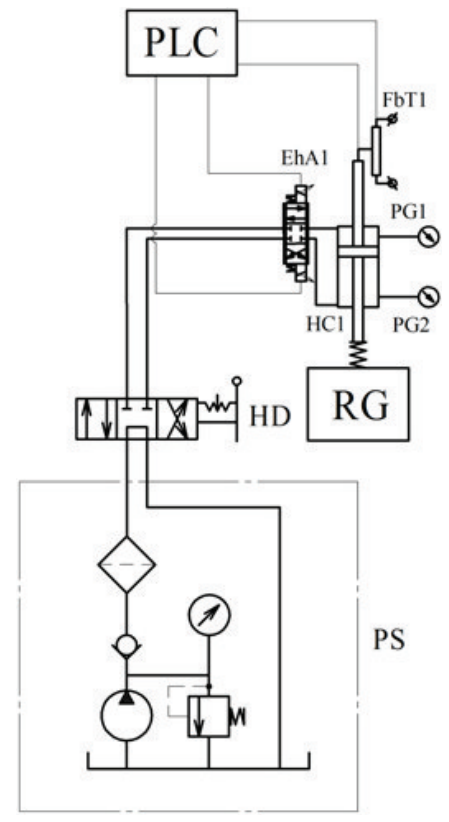

Fig.2. Fragment of hydraulic drive principle diagram: PS pumping station; HD hydraulic distributor; $\mathrm{RG}$ - ring gate; $\mathrm{HC1}$ - hydraulic cylinder; PG1,PG2 - pressure gauge; EhA1 - electrohydraulic amplifier; FbT1 - feedback transducer; PLC - program logic controller

Each drive unit is described by four nonlinear differential equations: the motion equation of electrohydraulic amplifier, the motion equation of actuator movable part, the equation of flow continuity through the pressure gaps of the spool and lower cylinder chamber and the continuity equation through the top cylinder chamber and drain gaps of the spool.

Thus, the first mathematical model included six systems of equations for each of the blocks and, in addition, equations for common loading moving and its turning. 


$$
\begin{aligned}
& m_{z i} \frac{d^{2} z_{i}}{d t^{2}}=K_{F J i}\left(J_{i}-K_{\mathrm{fb} i} x_{i}\right)-K_{v z i} \frac{d z_{i}}{d t}-C_{e m c i} z_{i} ; \\
& m_{1} \frac{d^{2} x_{1}}{d t^{2}}=\left(p_{11}-p_{21}\right) S_{1}-C_{s l 1}\left(x_{1}-X-0,5 R \varphi\right)- \\
& -K_{v x 1} \frac{d x_{1}}{d t}-m_{1} g-F_{c 1} \operatorname{sign}\left(\frac{d x_{1}}{d t}\right) \text {; } \\
& m_{2} \frac{d^{2} x_{2}}{d t^{2}}=\left(p_{12}-p_{22}\right) S_{2}-C_{s l 2}\left(x_{2}-X-R \varphi\right)- \\
& -K_{v x 2} \frac{d x_{2}}{d t}-m_{2} g-F_{c 2} \operatorname{sign}\left(\frac{d x_{2}}{d t}\right) \text {; } \\
& m_{3} \frac{d^{2} x_{3}}{d t^{2}}=\left(p_{13}-p_{23}\right) S_{3}-C_{s l 3}\left(x_{3}-X-0,5 R \varphi\right)- \\
& -K_{v x 3} \frac{d x_{3}}{d t}-m_{3} g-F_{c 3} \operatorname{sign}\left(\frac{d x_{3}}{d t}\right) \text {; } \\
& m_{4} \frac{d^{2} x_{4}}{d t^{2}}=\left(p_{14}-p_{24}\right) S_{4}-C_{s l 4}\left(x_{4}-X+0,5 R \varphi\right)- \\
& -K_{v x 4} \frac{d x_{4}}{d t}-m_{4} g-F_{c 4} \operatorname{sign}\left(\frac{d x_{4}}{d t}\right) \text {; } \\
& \left\{m_{5} \frac{d^{2} x_{5}}{d t^{2}}=\left(p_{15}-p_{25}\right) S_{5}-C_{s l 5}\left(x_{5}-X+R \varphi\right)-\right. \\
& -K_{v x 5} \frac{d x_{5}}{d t}-m_{5} g-F_{c 5} \operatorname{sign}\left(\frac{d x_{5}}{d t}\right) \text {; } \\
& m_{6} \frac{d^{2} x_{6}}{d t^{2}}=\left(p_{16}-p_{26}\right) S_{6}-C_{s l 6}\left(x_{6}-X+0,5 R \varphi\right)- \\
& -K_{v x 6} \frac{d x_{6}}{d t}-m_{6} g-F_{c 6} \operatorname{sign}\left(\frac{d x_{6}}{d t}\right) \text {; } \\
& M \ddot{X}=C_{s l 1}\left(x_{1}-X-0,5 R \varphi\right)+C_{s l 2}\left(x_{2}-X-R \varphi\right)+ \\
& +C_{s l 3}\left(x_{3}-X-0,5 R \varphi\right)+C_{s l 4}\left(x_{4}-X+0,5 R \varphi\right)+ \\
& +C_{s l 5}\left(x_{5}-X+R \varphi\right)+C_{s l 6}\left(x_{6}-X+0,5 R \varphi\right)- \\
& -M g-K_{v} \dot{X}-F_{c} \text {; } \\
& \mu_{i} \pi d_{z i} z_{i} \sqrt{\frac{2}{\rho}\left(P_{s}-p_{1 i}\right)}=S_{i} \frac{d x_{i}}{d t}+\frac{V_{1 i}}{E} \frac{d p_{1 i}}{d t} ; \\
& S_{i} \frac{d x_{i}}{d t}=\mu_{i} \pi d_{z i} z_{i} \sqrt{\frac{2}{\rho}\left(p_{2 i}-p_{c l}\right)}+\frac{V_{2 i}}{E} \frac{d p_{2 i}}{d t} ; \\
& J_{p} \ddot{\varphi}=F_{c} R-K_{\mathrm{M} \omega} \dot{\varphi}-K_{M \omega} R \sum_{i=1}^{6} C_{s l i} \varphi,
\end{aligned}
$$

where $m_{i}$ - mass of the $i$-th spool; $z_{i}$-displacement of the $i$-th spool; $K_{F J i}-$ electromagnetic converter gain of the i-th electrohydraulic amplifier; $J_{i}$ - control signal strength of current for the i-th electrohydrau- lic amplifier; $K_{f b i}$ - feedback factor of the $i$-th electromagnetic amplifier; $x_{i}-$ stroke of the $i$-th piston; $K_{v z i}-$ viscous friction coefficient of the $i$-th spool; $C_{\text {emci }}$ - spring stiffness of the $i$-th electromechanical converter; $m_{1.6}-$ mass of the $i$-s pistons; $p_{11 . .16}, p_{21.26}$ - pressures in lower and top chambers of hydraulic cylinders respectively; $S_{1 \ldots 6}-$ effective area of respective pistons; $K_{v x 1 \ldots 6}-$ viscous friction coefficient of respective pistons; $F_{c 1 . .6}-$ dry friction forces, applied to respective pistons; $\mu_{i}-$ coefficient of flow for the i-th spool; $P_{S}$ - supply pressure; $V_{1 i}, V_{2 i}$ - values of initial volumes of the lower and top hydraulic cylinders chambers respectively; $E$ - effective bulk modulus of working fluid; $C_{s l 1 . .6}$ - spring linkages stiffness of respective hydraulic cylinders with the common load; $X$ - displacement of the common load; $R$ - radius of the ring gate shield; $\varphi$ - rotation angle of the ring gate; $M-$ mass of the ring gate; $K_{v}$ - viscous friction coefficient of the gate; $F_{c}-$ dry friction force, applied to the gate; $J_{p}$ - polar moment of inertia for the ring gate shield; $K_{m \omega}-$ viscous friction load coefficient; $K_{M \varphi}-$ positional load coefficient.

The system of differential equations was solved in an integrated environment MATLAB using built-in functions ODE23s.

In the second model was considered hydraulic drive, working with ring gate, conventionally divided into six unrelated among themselves parts. Kinematic diagram of the second model is shown in fig.3.

It was assumed that such a simplified scheme may be useful in the practice of design, when it is necessary to fast (rapid) assessment of the design feature impact on the proposed design solution. Assumptions and initial conditions are taken the same to accepted in the case of model with common gate. Each of the drive, included in hydraulic system, is also described by four nonlinear differential equations: motion equation of electrohydraulic amplifier spool; motion equation of movable part of hydraulic drive; continuity equation through the pressure gaps of spool valve and a lower chamber of hydraulic cylinder and continuity equation through the top chamber of hydraulic cylinder and drain gaps of spool valve.

Thus, the second mathematical model includes 6 systems of equations of the following form: 


$$
\left\{\begin{array}{l}
m_{z i} \frac{d^{2} z_{i}}{d t^{2}}=K_{F J i}\left(J_{i}-K_{\mathrm{fb} i} x_{i}\right)-K_{v z i} \frac{d z_{i}}{d t}-C_{e m c i} z_{i} ; \\
m_{i} \frac{d^{2} x_{i}}{d t^{2}}=\left(p_{1 i}-p_{2 i}\right) S_{i}-K_{v x i} \frac{d x_{i}}{d t}-m_{i} g-F_{c i} \operatorname{sign}\left(\frac{d x_{i}}{d t}\right) \\
\mu_{i} \pi d_{z i} z_{i} \sqrt{\frac{2}{\rho}\left(P_{p}-p_{1 i}\right)}=S_{i} \frac{d x_{i}}{d t}+\frac{V_{1 i}}{E} \frac{d p_{1 i}}{d t} \\
S_{i} \frac{d x_{i}}{d t}=\mu_{i} \pi d_{z i} z_{i} \sqrt{\frac{2}{\rho}\left(p_{2 i}-p_{c l}\right)}+\frac{V_{2 i}}{E} \frac{d p_{2 i}}{d t} .
\end{array}\right.
$$

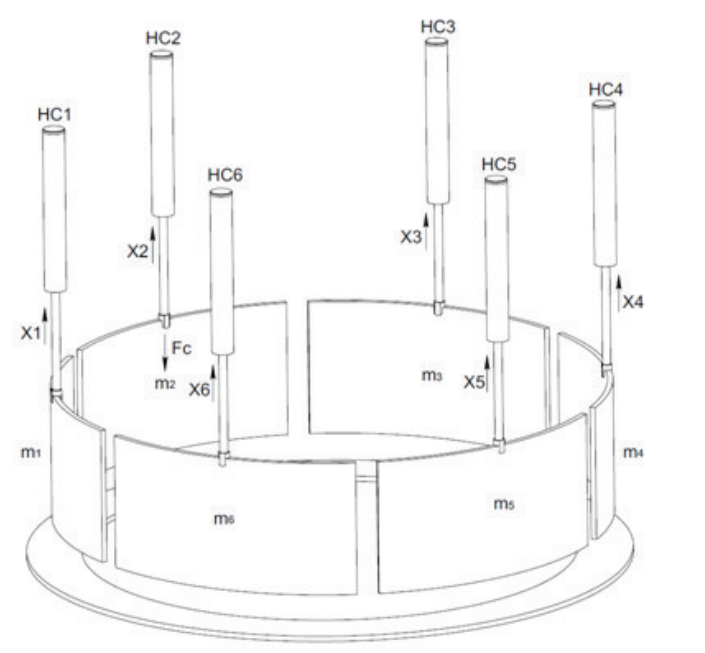

Fig. 3. Kinematic scheme of servodrive

The system of differential equations was solved in a similar way. Calculations showed that at a uniform distribution of the load, the mass attributed per each cylinder, will be equal to $10 \mathrm{t}$. With this load cylinders are moved synchronously, and synchronization error is absent. During carrying out the numerical experiment, deviation from nominal mass in the range of -100 to $387 \%$ for one of the cylinders was set. Thus, in the final phase of experiment, gravity force of the load was comparable with maximum force, which can be achieved by hydraulic cylinder. According to the results of this numerical experiment, dependence has been built, as shown in fig. 4 .

On the horizontal axis in fig. 4 value of relative load is plotted:

$$
M_{\text {rel }}=\frac{m g}{P_{s} S_{p}},
$$

where $m$ - load mass, moving by hydraulic cylinder; $g$ - acceleration of gravity; $S_{p}$ - effective area of the piston;

On the vertical axis in fig. 4 relative synchronization error of piston displacement is plotted:

$$
\Delta_{\text {rel }}=\frac{\Delta}{\Delta_{\max }},
$$

where $\Delta$ - instantaneous synchronization error; $\Delta_{\max }-$ permissible error.

From fig. 4,a can be seen, that dependence has a non-linear character and error value increases dramatically when approaching gravity force of the load to the maximum value, which can be achieved by hydraulic cylinder. However, in the values area, limited by permissible value of synchronization error $(4 \mathrm{~mm})$, characteristic is linear (fig. 4,b).

a)

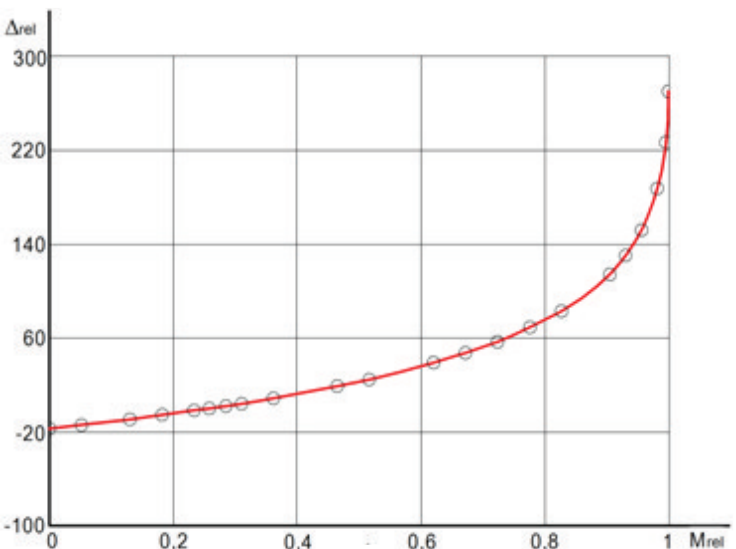

b)

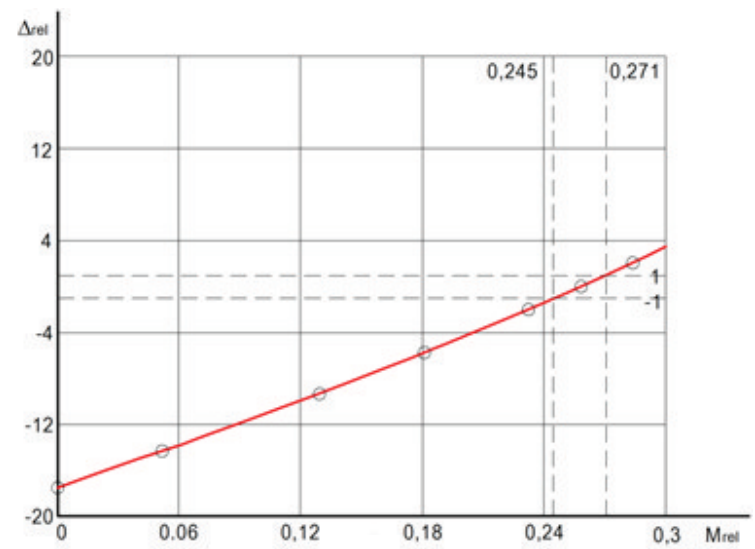

Fig. 4. Dependence of synchronization error of hydraulic cylinders displacement from mass deviation from nominal value in whole range of mass change $(a)$ and in a range, limited by permissible error $(b)$

Analysis of fig. 4,b allows concluding that permissible value of synchronization error is limited by the ratio of the load weight to the maximum force equal to $27,5 \%$. Thus the deviation of load mass from the nominal value is $6,6 \%$.

During carrying out the numerical experiment, external load in the range from 0 to $\mathrm{N}$ was applied to one of the hydraulic cylinders additionally apart gravity 
force. According to results of this numerical experiment, dependence has been built, as shown in fig. 5 .

a) $\Delta_{\mathrm{r}}$

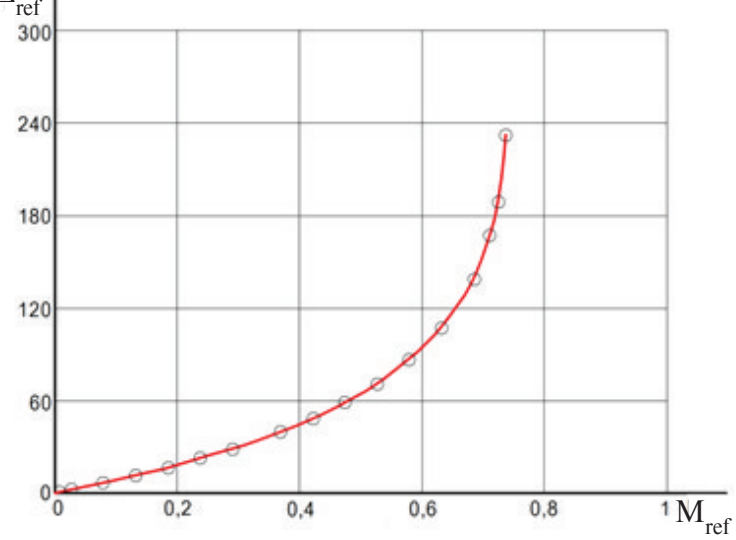

b)

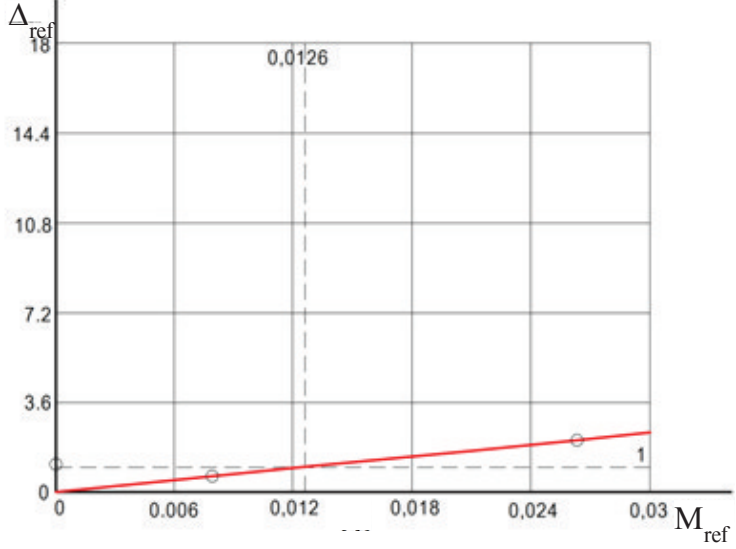

Fig. 5. Dependence of synchronization error of hydraulic cylinders displacement from external load, applied to one of the cylinder in whole range of mass change $(a)$ and in a range, limited by permissible error $(b)$

On the horizontal axis in fig. 5 value of relative load is plotted:

$$
M_{\mathrm{rel} F}=\frac{F_{\mathrm{ex}}}{P_{S} S_{p}},
$$

where $F_{e x}-$ external force additionally applied to hydraulic cylinder.

On the vertical axis in fig. 5 relative synchronization error of piston displacement is plotted as in fig. 4.

From fig. 5, $a$ it is evident that dependence of synchronization error from external load, applied to the cylinder, is also non-linear, but in range of values, limited by permissible synchronization error, is a linear function (fig. $5, b$ ).

Analysis of fig. $5 b$ allows to conclude that permissible value of synchronization error is limited by the ratio of external force is additionally applied to hydrau- lic cylinder to the maximum force equal to $1,26 \%$, i.e., maximum value of external load is $4792 \mathrm{~N}$.

Impact of cylinders areas (diameter) difference, which was obtained in the course of numerical experiment, is shown in fig. 6. During calculations, diameter of the cylinder pistons was changed within tolerance, which in the manufacture of piston according to $\mathrm{h} 8$, is $89 \mathrm{mkm}$ for $320 \mathrm{~mm}$ nominal diameter.

On the vertical axis in fig.6 parameter $\Delta D_{\text {rel }}$ is plotted:

$$
\Delta D_{\text {rel }}=\frac{\Delta D}{\Delta D_{\max }}
$$

where $\Delta D$ - instantaneous value of diameter deviation from nominal; $\Delta D_{\max }-$ maximum value of diameter deviation.

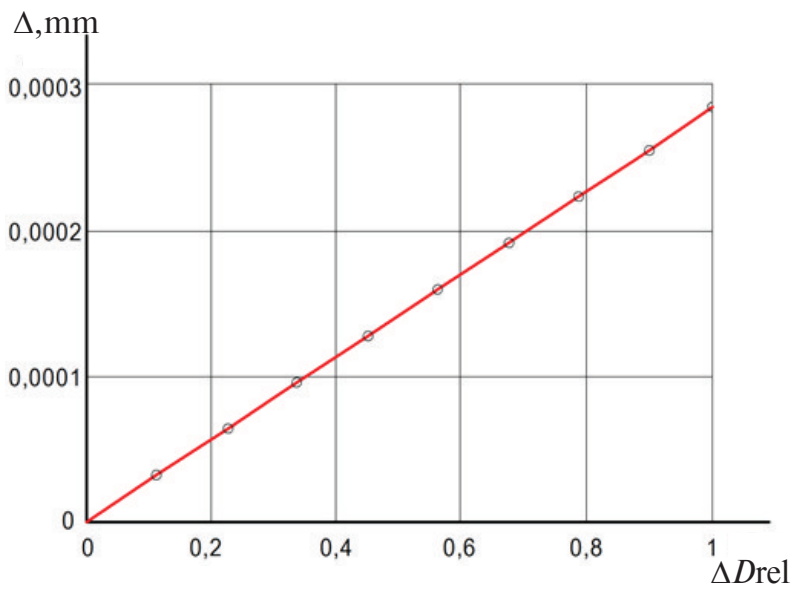

Fig. 6. Dependence of synchronization error from changing the diameter of one of the hydraulic cylinders

On the vertical axis in fig. 6 absolute value of synchronization error is plotted.

From fig. 6 it is evident that the synchronization error caused by the change in the diameter of one of the hydraulic cylinders, relative to the nominal value is linear. Maximum synchronization error at a deviation of the piston diameter from the nominal value at 89 microns is $0,284 \mathrm{~mm}$.

Thus, the study of mathematical model of multiactuator drive with independent mass showed that:

maximum overload of the drive, caused by different values of moved mass, relative to maximum force of the drive, at which synchronization error is within acceptable limits, is not more than $27,5 \%$, or $6,6 \%$ relative to the nominal value of the load.

external load, which are additionally applied to hydraulic cylinder, in addition to the current gravity force of the load, also has a significant impact on 
synchronicity work of drives. Permissible value of external force to the maximum force is $1,26 \%$.

synchronization error, which is caused by an error within the manufacturing tolerance is insignificant and does not exceed $7 \%$ of permissible synchronization error, but due to the action of other factors must be taken into account.

The study of multi-actuator drive mathematical model with a common load allows making the following conclusion:

the presence of common load substantially reduces synchronization error caused by the action of external forces applied directly to the cylinders, how- ever, makes the drive more responsive to forces applied directly to the gate. The latter is due to the fact that these forces act on significant shoulders (up to $4,5 \mathrm{~m}$ ), as a consequence, create considerable overturning moments.

The executed theoretical study of multi-actuator hydraulic drive of ring gate for hydraulic turbine, allows to determine common factors of this drive operation, to identify the most influencing factors, and to assess their negative impact on the synchronized movement of pistons and develop sound recommendations for choice of the main parameters of hydraulic drive.

\section{REFERENCES}

1. Navrotskiy K.L. Analiz dinamiki sinkhronnogo gidroprivoda koltsevogo zatvora gidroturbiny. Russian Engineering Research. 2005. № 2. S. 3-8. (rus.)

2. Potetenko O.V., Shevchenko N.G., Koval Ie.S. Chislennoye modelirovaniye gidrodinamicheskogo usiliya, deystvuyushchego na koltsevoy zatvor v protsesse yego opuskaniya $\mathrm{v}$ protochnuyu chast radialno-osevoy gidroturbiny. HPI publ. Kharkov. 2012. № 54. S. 176-186. (rus.)

3. Shevchenko N.G., Koval E.C. Prognozirovaniye gidravlicheskoy sily vozdeystviya potoka vody na koltsevoy zatvor gidroturbiny.[Prediction of hydraulic power fl ow impact water annular valve turbines]. Modern Directions of theoretical and applied researches. 2013. № 2. S. 74-81. (rus.)

4. Deng Yingjian. Research on active synchronous control system of hydraulic press and its reliability analysis. Second International Conference on Digital Manufacturing\&Automation. 2011. P. 940-943.

5. Dou Haibin, Wang Shaoping. Synchronization Control of Hydraulic Horizontal Regulation System. 6th IEEE Conference on Industrial Electronics and applications. 2011. P. $1922-1927$.

\section{СПИСОК ЛИТЕРАТУРЫ}

1. Навроцкий К. Л. Анализ динамики синхронного гидропривода кольцевого затвора гидротурбины // Вестник машиностроения. 2005. № 2. С.3-8.

2. Потетенко О.В., Шевченко Н.Г., Коваль Е.С. Численное моделирование гидродинамического усилия, действующего на кольцевой затвор в процессе его опускания в проточную часть радиальноосевой гидротурбины // Вісник НТУ “ХПІ". 2012. № 54. C. 176-186.

3. Шевченко Н.Г., Коваль Е.С. Прогнозирование гидравлической силы воздействия потока воды на кольцевой затвор гидротурбины // Modern Directions of theoretical and applied researches. 2013. № 2. C. 74-81.
6. Guo Chunli, Guodong Wang, Juliang Xiao. Numerical Simulation for Hydraulic Characteristics of Cylindrical Valve in Runaway Protection Process. Power and Energy Engineering Conference. APPEEC. 2009. Asia - Pacific. - P. 201-205.

7. Guo Chunli, Li Zhifeng, Du Chenyang, Wang Fengyang. QFT Synchronous Control System of Ring gate for Hydraulic Turbine. Power and Energy Engineering Conference. APPEEC. 2009. Asia - Pacific. P. 221-225.

8. Jiangtao Tu, Minghui Huang. Simulation Research of a Synchronous Balancing System for Hydraulic Press Based on AME / Simulink. International Conference on Measuring Technology and Mechatronics Automation. 2009. P. 359-362.

9. Xiao Juliang, Wang Guodong, Song Weike. Electrohydraulic proportional Synchronous Control System of Ring gate for Hydraulic Turbine. Power and Energy Engineering Conference. APPEEC. 2009. Asia-Pacific. 2009. P. 142-147.

10. Jiangtao Tu, Minghui Huang. Simulation Research of a Synchronous Balancing System for Hydraulic Press Based on AME / Simulink. International Conference on Measuring Technology and Mechatronics Automation. 2009. P. 359-362.

4. Deng Yingjian. Research on active synchronous control system of hydraulic press and its reliability analysis // Second International Conference on Digital Manufacturing\&Automation. 2011. S. 940-943.

5. Dou Haibin, Wang Shaoping. Synchronization Control of Hydraulic Horizontal Regulation System// 6th IEEE Conference on Industrial Electronics and applications. 2011. S. 1922-1927.

6. Guo Chunli, Guodong Wang, Juliang Xiao. Numerical Simulation for Hydraulic Characteristics of Cylindrical Valve in Runaway Protection Process // Power and Energy Engineering Conference. APPEEC 2009. Asia - Pacific. S. 201-205. 
7. Guo Chunli, Li Zhifeng, Du Chenyang, Wang Fengyang. QFT Synchronous Control System of Ring gate for Hydraulic Turbine. Power and Energy Engineering Conference. APPEEC 2009. Asia - Pacific. P. 221-225.

8. Jiangtao Tu, Minghui Huang. Simulation Research of a Synchronous Balancing System for Hydraulic Press Based on AME/Simulink. International Conference on Measuring Technology and Mechatronics Automation. P. 359-362.
9. Xiao Juliang, Wang Guodong, Song Weike. Electrohydraulic proportional Synchronous Control System of Ring gate for Hydraulic Turbine. Power and Energy Engineering Conference. APPEEC. 2009. Asia-Pacific. P. 142-147.

10. Jiangtao Tu, Minghui Huang. Simulation Research of a Synchronous Balancing System for Hydraulic Press Based on AME/Simulink. International Conference on Measuring Technology and Mechatronics Automation. 2009. P. 359-362.

\section{СВЕДЕНИЯ ОБ АВТОРАХ/AUTHORS}

MATROSOV Artiom V. - Peter the Great St. Petersburg Polytechnic University.

29 Politechnicheskaya St., St. Petersburg, 195251, Russia.

E-mail: a.matrosov.hydro@mail.ru

МАТРОСОВ Артем Владимирович - аспирант Санкт-Петербургского политехнического университета Петра Великого.

195251, Россия, г. Санкт-Петербург, Политехническая ул., 29.

E-mail: a.matrosov.hydro@mail.ru

ISAEV Yurii M. - Peter the Great St. Petersburg Polytechnic University.

29 Politechnicheskaya St., St. Petersburg, 195251, Russia.

E-mail: ymi30@mail.ru

ИСАЕВ Юрий Митрофанович - кандидат технических наук профессор Санкт-Петербургского политехнического университета Петра Великого.

195251, Россия, г. Санкт-Петербург, Политехническая ул., 29.

E-mail: ymi30@mail.ru

SUNARCHIN Robert A. - Peter the Great St. Petersburg Polytechnic University.

29 Politechnicheskaya St., St. Petersburg, 195251, Russia.

E-mail: sunar1939@mail.ru

СУНАРчИН Роберт Авалевич - кандидат технических наук доцент Санкт-Петербургского политехнического университета Петра Великого.

195251, Россия, г. Санкт-Петербург, Политехническая ул., 29.

E-mail: sunar1939@mail.ru 